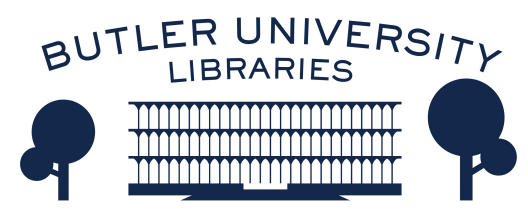

Journal of Hindu-Christian Studies

\title{
Some Thoughts on God and Spiritual Practice in Yoga and Christianity
}

\author{
Bradley Malkovsky \\ University of Notre Dame
}

Follow this and additional works at: https://digitalcommons.butler.edu/jhcs

Part of the Christianity Commons, and the Religious Thought, Theology and Philosophy of Religion Commons

\section{Recommended Citation}

Malkovsky, Bradley (2017) "Some Thoughts on God and Spiritual Practice in Yoga and Christianity," Journal of Hindu-Christian Studies: Vol. 30, Article 5.

Available at: https://doi.org/10.7825/2164-6279.1657

The Journal of Hindu-Christian Studies is a publication of the Society for Hindu-Christian Studies. The digital version is made available by Digital Commons @ Butler University. For questions about the Journal or the Society, please contact cbauman@butler.edu. For more information about Digital Commons @ Butler University, please contact digitalscholarship@butler.edu. 


\section{Some Thoughts on God and Spiritual Practice in Yoga and Christianity}

\section{Bradley Malkovsky University of Notre Dame}

I do not approach this topic as an expert historian of the diverse schools of yoga or as a systematician of their teachings or as an exegete of their classical texts. ${ }^{1}$ Rather I address the theme of yoga and Christianity as a Christian theologian who has been a practitioner of Iyengar yoga, a prominent method of modern postural yoga, for more than thirty years and who has done some scholarly reading on contemporary and classical yoga and on Patanjali's Yoga-Sutra (hereafter YS) in particular. ${ }^{2}$ Despite all the controversy that has arisen in recent years about whether or not Christians should be practicing yoga, my own spiritual life has been greatly enriched by the yoga practice and the teachings of B. K. S. Iyengar (1918-2014) ${ }^{3}$ as well as by some of the writings of contemporary scholars on the YS and the YS's subsequent history of commentary. ${ }^{4}$ In what follows I offer some thoughts on the possible value of yoga for Christians, about which much has already been written, ${ }^{5}$ but I will also reflect on a few challenges that emerge when one attempts to unite yoga theory and practice with Christian teaching and spirituality. My main focus will be on the conception of the Lord (Ishvara) in the YS, on the notion of God in the teachings of Mr. Iyengar, and on the understanding of God in Christianity, so as to show where these views on the divine align and where they diverge.

I would like to further preface my thoughts on the possible benefits of yoga practice for Christians by stating that I have never been interested in synthesizing yoga postures (asanas) with Christian prayer or devotion. I know that some yoga methods want to synthesize the two, i.e. attach Christian prayers to the performance of individual yoga asanas, ${ }^{6}$ but for me that approach does not represent the kind of simple yoga practice culminating in the type of egoless awareness that the YS and Iyengar postural yoga are about. I believe in letting such yoga practice as taught by Iyengar teachers preserve its integrity and independence from Christian influence, even though the practice of yoga in its various forms through the centuries has shown itself to be quite malleable and adaptive, being capable of integration into a wide variety of religions and

Bradley Malkovsky was the editor of the Journal of Hindu-Christian Studies (formerly the Hindu-Christian Studies Bulletin) from 2002-2017. He earned his doctorate at the University of Tübingen on the soteriology of Adi Shankara. His God's Other Children: Personal Encounters with Faith, Love, and Holiness in Sacred India (HarperOne 2013) won the Huston Smith Publishing Prize. He teaches comparative theology at the University of Notre Dame, USA. 
visions of life. ${ }^{7}$ In other words, I see benefit for Christians like myself practicing Iyengar yoga without trying to first change it or adapt it in any way because of some perceived deficiency in yoga teaching and practice when compared to Christian thought and spirituality. With this approach I allow the possibility of being impacted by a very different experience of transcendence than that offered by Christianity. At the same time that I readily acknowledge such a beneficial impact of yoga practice and experience on myself as a Christian practitioner, I also recognize a number of questions and unavoidable challenges that arise from the standpoint of Christian faith. There are some key differences in yogic and Christian spirituality and experience that are rooted in very different understandings of the divine and the human person. I think at times it is difficult to conceptually reconcile these two different experiences of transcendence without giving primacy to one over the other, even when both reveal themselves as valuable.

In what follows I begin by pointing out what I consider to be some convergences in yogic and Christian spirituality followed by some reflections regarding the value of yoga practice for Christians before finally discussing, from the Christian perspective, some significant differences with regard to yogic and Christian spirituality.

\section{The Ethical and Ascetic Convergence of Yoga and Christian Spirituality}

Iyengar Yoga, basing itself on the ashtangayoga teachings of the YS, ${ }^{8}$ i.e. the yoga with the "eight limbs," has revealed itself in the contemporary world to be of great benefit physically and spiritually for people of diverse backgrounds, and this includes many Christian practitioners. The yamas or moral restraints, ${ }^{9}$ i.e. the first limb of ashtanga-yoga, teach that there can be no enlightenment or liberation from interior suffering without the elimination of every trace of self-centered attachment and desire. It is not enough to simply bring the mind to a state of no longer generating thoughts or ideas. There cannot be even the slightest trace or impulse toward selfishness, whether conscious or subconscious, if one wants to attain perfect inner freedom. The yamas ideally act as a mechanism to prevent yoga practice from falling prey to narcissism, self-centeredness, and self-interested desire. And thus the yamas, the moral foundation prescribed in the YS, resonate with the selflessness demanded of the followers of Jesus, despite significant differences between the two visions of life and their respective final goals. ${ }^{10}$

The second limb of this eightfold yoga path, the niyamas or ascetical disciplines, ${ }^{11}$ like the yamas, helps to throw off the yoke of ego and help one heal and overcome the fragmented nature of one's life, so as to bring about order and harmony. Many Christians will immediately recognize an affinity with some of these yamic and niyamic principles and practices with their own Christian ascesis and moral ideals. The disciplining of the body, the striving to overcome all selfishness in one's interaction with other persons and objects, the focus on keeping both mind and heart pure, the attempt to avoid sexual license, all these themes are more or less familiar to the spiritual life of the practicing Christian.

\section{Some Additional Benefits of Yoga Practice for Christians $^{12}$ \\ Given this ethical and ascetical convergence between yoga and Christian spirituality, what is}


it about yoga practice that attracts so many Christians as an aid to their spiritual development?

First, yoga takes a very holistic approach to spirituality, as both body and mind are deliberately and systematically brought under control and made to serve spiritual ends. The attainment of this goal involves sustained attention to the body and the mind as vehicles or tools for spiritual growth. In yoga practice one becomes more attentive to the changing states of body and mind. One learns the deep connection between physical and mental discipline, between breath and mind, and even the impact of diet on one's spiritual awareness. Yoga teaching thus offers very elaborate practical advice, impacting one's mental, physical, and spiritual dimensions.

With regard to the place of the body in spiritual practice, there is really nothing like yoga's physical postures (asanas) in Christian practice, not even in Eastern Christianity's combining of hesychastic prayer with certain bodily positions. The yogic use of balance and stretching as a practical means to slow down the mind and enable it to remain focused in the present moment helps to overcome the restlessness and lack of attention that is sometimes experienced in meditation and prayer. Physical practice can thus be a way of settling into silence, of providing a bridge from a scattered to a more focused state of mind.

Second, one discovers the calming effect of yoga meditation and its capability, if done in combination with the yamas, to help uproot self-centered awareness. This, of course, can also be experienced in meditation systems that have nothing to do with yoga.

Third, through yoga practice Christians can learn just how much can be accomplished already in the spiritual life through effort alone. With determination and with the practice of the yamas as a strong moral foundation, one can orient one's mind toward virtue, selflessness, and inner silence. This does not mean that spiritual and moral perfection or even the final goal of the Christian spiritual life, namely union with God in love, can be accomplished through effort alone. But yoga practice does reveal that even in a religion of grace like Christianity one might learn to give greater attention to effort than one is normally accustomed to doing.

\section{Questions about "God" in the YS}

What I have said so far has focused primarily on yoga practice. But now I want to address what is the main topic of this essay, which is God. By "God" I mean someone, a supreme Person, who is professed by all Christian and most Hindu theologies as a transcendent and merciful creator, who is immanent to all creation, oneness with whom is the goal of the spiritual life. The obvious big question here is whether there is anything like God in the YS, for the YS is my starting point in reflecting on God and yoga. It is the text upon which Mr. Iyengar based his teaching. But, as will be seen, Mr. Iyengar's understanding of God diverges in significant ways from the understanding of the "Lord" (Ishvara) in the YS. In fact, in some respects Mr. Iyengar's understanding of God is closer to the Christian understanding of a supreme transcendent reality than it is to the Lord of the YS. The Lord in Mr. Iyengar's understanding is more clearly personal and grace-giving than is the Lord of the YS. I will elucidate on this in what follows.

I am of the opinion that the YS term "Ishvara" ("the Lord") does not refer to anything like God as I have described God in the 
preceding paragraph. A number of well known yoga scholars, people like Gerald Larson, would agree. Ishvara is rather something like a limited spiritual 'monad' (purusha). Larson writes, "if God [in the YS] is a purușa, God cannot be personal nor any kind of cosmic absolute. . . the Yoga God is untouched (aparāmrșta) and, hence, uninvolved in the transactions of afflictions, action, and the karmic ripening of traces (YS I.24). Hence, God in Yoga becomes an impersonal, acosmic, detached presence whose inherent contentlessness can only show itself as what it is not." 13

But I am also aware that Ishvara is a disputed topic in YS research, perhaps the most controversial of all topics. Recently other very accomplished scholars of the history of Hindu thought and of the YS have taken the opposite view from that of Larson, people such as Edwin Bryant ${ }^{14}$ and Graham Schweig. ${ }^{15}$ They understand Ishvara in the YS to be transcendent in ways that are similar to how Christian and Hindu theists tend to understand God, namely as creator of the world and giver of grace. Bryant, for example, argues that Patanjali's Ishvara should be regarded as belonging to the general Hindu understanding of a personal God characteristic of most bhakti or devotional movements of Patanjali's time. ${ }^{16}$ He says, "one ... cannot extricate and immunize Patañjali’s Íśvara from the theological landscape of his time." ${ }^{17}$ Bryant goes so far as to suggest that Patanjali was "necessarily" a devotee of either Vishnu or Shiva. ${ }^{18}$

As to divine grace, the word "grace" is not used anywhere in the YS, but there is one instance where the Lord is said to be a helper and, by inference, a giver of grace. YS I.26 states that Ishvara is the teacher (guru) of the ancient seers, which might be construed as a kind of grace or help, though what this means exactly is not clarified. After this initial action the Lord does nothing. Once a person learns of the yoga path, they are on their own to apply it to their life, relying on self-effort and their teacher to attain liberation. Patanjala yoga in this understanding, then, was originally a self-help discipline.

What about the famous ishvara-pranidhana ("surrender to the Lord") of YS I.23? Could this imply surrendering oneself to the power of a gracious personal God? I accept the position of Larson, who states, "'The term pranidhāna is not bhakti or devotional theism in any conventional sense ... it is a deep meditation on the nature of transcendence, not any sort of devotional theism." ${ }^{19}$

When Patanjali thus prescribes ishvarapranidhana, "surrender to the Lord," what he is talking about is meditation practice, not prayer to a divine Person or the surrender of oneself to the power of another. Meditation is not an interpersonal spiritual discipline; it is the harnessing of one's unruly mind through the mental focus on one or another object. "Surrender to the Lord" in the YS simply means meditation on the Lord's reality and perfection, so as to calm the mind and prepare it for enlightenment. In sum, the Lord is a help to the practitioner, not because the Lord actively does anything for the yogi, but rather because a person's choice to make Ishvara the object of their meditation is beneficial to their spiritual development. Meditation on the Lord purifies and pacifies one's mind. Since, in this understanding, the Lord of the YS is not understood to be interactive or responsive to the prayers of the yoga practitioner, it makes sense that Patanjali would place "surrender to the Lord" as part of the niyamas instead of 
including it with the yamas. The yamas, the first limb of ashtanga yoga, are a set of restraints that govern one's relation and even interaction with other realities, whether they be persons or things. The yamas, in short, apply to yoga practitioners as social beings. By contrast, the niyamas, the second limb of the yoga path, guide practitioners in their activities as individuals not interacting with their surroundings. And that is why, I believe, Patanjali positions "surrender to the Lord" under the niyamas. For Patanjali there is no real interaction between the Lord and suffering purushas, certainly no dynamic interactive relation of Lord and devotee. Hence it makes perfectly good sense to place talk of Ishvara in the category of niyamas rather than with the yamas. ${ }^{20}$

And so if I take the position of Larson, that is, if in fact Ishvara in the YS is not really God, but something very different from God ontologically and soteriologically speaking, then it will be difficult to find similarities between Ishvara and what Christians mean by the supreme reality. For God, according to all Christian theologies, is creator of the world, is omnipresent and is the ultimate goal of all spiritual striving. But Ishvara in the YS is, as I read it, none of these. It is neither the creator of the world nor all-pervasive nor is it the goal of the spiritual quest. And so one can never be united with Ishvara, although one is always like Ishvara in one's deepest hidden nature, which is pure consciousness, not subject to the five kleshas or afflictions. Enlightenment is simply the shining forth of this eternal nature, but it is never a spiritual communion of a limited self with Ishvara. And it has nothing to do with divine love.

Regardless of which interpretation of the YS is correct with respect to whether or not Ishvara is God, the fact is Ishvara is clearly regarded as God in later yoga texts and traditions. How this development took place from a limited understanding of the "Lord" in the YS to a more complete understanding of the Lord as God in later yoga texts and traditions is not my concern here. ${ }^{21}$ I am less interested in who is right and who is wrong about how best to understand Ishvara in the YS. I am much more interested in how the God of postural yoga is often understood today and how this understanding might or might not converge with the Christian notion of God. In what follows my focus on God in contemporary postural yoga will be on the way B. K. S. Iyengar understands the divine.

\section{"God" for B. K. S. Iyengar}

As already noted, B. K. S. Iyengar bases his teaching on the YS. Although he offers no developed theology or philosophy about God's nature and activity in his writings, he will explicitly refer to Ishvara as "God." ${ }^{22} \mathrm{He}$ begins his most famous work, Light on Yoga, with the following invocation: "I salute Ādiśvara (the Primeval Lord Śiva) who taught first the science of Hatha Yoga - science that stands out as a ladder for those who wish to scale the heights of Rājā Yoga." ${ }^{23}$ Ishvara is thus identified with one of the most popular names for the personal creator God in Hindu theological and devotional discourse.

Elsewhere Mr. Iyengar expands the notion of the supreme reality to include words from the Upanishads and Vedanta such as Brahman and Atman. "In Indian thought," he writes, including yoga, "everything is permeated by the Supreme Universal Spirit (Paramātmā or God) of which the human spirit (jīvātmā) is a part. The system of yoga is so called because it teaches the means by which the jivātmā can be united to, or be in 
communion with the Paramātmā, and so secure liberation (mokșa)." ${ }^{24}$ Elsewhere he speaks of prana as "God's breath" and even goes so far as to connect it with the Holy Spirit in Christianity, comparing it to the same force that hovered over the waters at the beginning of the book of Genesis. ${ }^{25}$ He further states that the goal of the spiritual quest, namely samadhi, which is the transcendence of all duality and the liberating experience of the divine at the core of one's being, is a "supreme gift" that is granted "by the grace of God." ${ }^{26} \mathrm{He}$ adds that as one's lower consciousness is purified, "the existence of the Cosmic Force can be felt. As one increasingly feels the existence and pull of the Divine, one's actions more easily align with the ethical impulse of the Absolute." ${ }^{27}$ Also, he says, "The Divine Will impels humankind to ... the ultimate surrender... You surrender to the Lord, and the Lord accepts your surrender." ${ }^{28}$ It is striking how such personalist phrases as the "grace of God" and the "Divine Will" are explicitly mentioned here, when they are entirely absent from the YS. In addition, Mr. Iyengar, unlike the YS, speaks of God as the creator of the world, ${ }^{29}$ and he speaks approvingly of Ramanuja, a Vedantic theist, with regard to the spiritual life. ${ }^{30} \mathrm{He}$ will even occasionally state that a person ultimately finds the "love of God" in spiritual experience. ${ }^{31} \mathrm{He}$ is cited as saying, "All the other yogas; karma, hatha, jnana, and raja, all culminate in bhakti yoga, the yoga of love and devotion, the yoga of the heart." ${ }^{32}$ Nevertheless, such talk of divine love is rare and certainly less central to Mr. Iyengar's overall teaching than is talk of self-realization.

We thus notice a fluidity of terms and an expansive understanding of the divine in the writings of B. K. S. Iyengar. Where do they all come from? Mr. Iyengar's upbringing was as a
Srivaishnava Brahman, ${ }^{33}$ and it is likely that the bhakti elements of his faith derive from there. However, he did not publicly, either orally or in writing, ever advocate Srivaishnava teaching or the thought and spirituality of Ramanuja, the Srivaishnavite Vedantin, as superior to other systems. Neither did he deny their value. According to the essay by Smith and White, with regard to Vaishnavism Mr. Iyengar had "few inhibitions in allowing this aspect of his life and personality to passively leak into and permeate his yoga teachings and persona as a guru. Although he has not dwelled on this, neither has he denied it." ${ }^{34}$

Mr. Iyengar saw himself as simultaneously a yogin and a Vedantin, as a disciple of both Ramanuja and Patanjali. In an interview in 2011 he stated that he understood the Ishvara of the YS to be Vishnu. He did not seem to be concerned about reconciling the diverging ontologies of Samkhya's dualism and Ramanuja's nondualism. ${ }^{35}$

It is unclear exactly how Mr. Iyengar understood divine grace beyond the few phrases just cited or what else God might be presumed to be doing. Although his language does indicate a personal God who is free to act and bless at will, the focus of Mr. Iyengar's yoga was always on one's effort in practicing the asanas to bring about liberating awareness, and little mention is made of prayer or the need for God's grace for yoga practitioners to advance in the spiritual life. Here devotion to God seems entirely optional. With this focus on yoga practice and meditation, the personal interactive Lord seems to fade into the background. And with regard to the final goal of the yogic quest, it was more typical of Mr. Iyengar to speak of attaining the freedom of an egoless state of consciousness than it was to proclaim union with God in love as the goal. 
Here God is primarily the help to the goal, but not the goal itself. In that sense Mr. Iyengar's path is very different from Hindu bhakti schools and Christian spirituality, which place divine love squarely at the center of their spiritual praxis and teaching and which make spiritual liberation and union with God in love virtually synonymous.

\section{"God" in Christian Discourse}

Having made these very introductory observations about the fluidity and openendedness of the notion of the divine in Iyengar Yoga, an understanding that I believe is also common today among postural yoga practitioners from other schools, I would like to reflect a bit on some basic beliefs about God and spirituality in Christianity and point out a few significant points of difference with yoga. These differences include the degree of God's active involvement in human life, the understanding and value of the human person, and the final aim and goal of human life. These points are tightly interconnected, as are all theological anthropologies and soteriologies. Some of these differences with yoga teaching help explain the reluctance of some Christians to embrace yoga, though I do not personally believe it automatically rules out yoga's compatibility with Christian faith and praxis.

First, in Christian spirituality the love and mercy of God are absolutely crucial for the spiritual quest. That is because pure consciousness is not the goal, but rather communion with God in love. In Christian understanding divine grace is the starting point for one's relation with God, not human effort. Human effort is the response to God taking the initiative in reaching out to the human person to establish a relationship of love. This is seen most clearly in the life and teaching of Christ, who represents divine mercy going so far as to take on the human condition of vulnerability, suffering, and even death to win over the human heart. This is a free and unconditional offer of divine love to all people, even to those people who do not even seek to know God or seek spiritual development. God's activity is not a reward for human effort. Accordingly it is the transformative power of divine love that is the remedy for selfish ego-centered awareness, which in Christianity is called "sin." The level of freedom and inner purity achieved on the basis of one's effort alone is insufficient to bring about the kind of freedom that is grounded in a relationship of love. If God is Person, ${ }^{36}$ as Christianity and Hindu bhakti teach, then intimacy with God can never be presumed or achieved through effort alone. It comes as a gift. We might reflect a bit on why it is that no amount of human effort by itself can create union with a personal God or, for that matter, with any human person. It belongs to the very definition of persons, whether divine or human, that they are able to freely choose to reveal themselves and to bestow their presence upon another. For a relationship of love to emerge, there has to be a mutual unveiling and self-gift of one person to the other and even a mutual surrender. In Christian understanding God surrenders to humanity on the cross, thereby countering human violence and sin with patience and mercy. The purpose of such activity is to woo the human heart and awaken it to love, not to force an unwilling human being into submission.

Second, there is, of course, nowhere in yoga anything like resurrection faith, understood as the completion of the human person in God, in both its spiritual and bodily natures. By 
contrast, if one examines the anthropology and teaching of liberation from any Hindu text or school having to do with yoga, one will see that the human person as such cannot be perfected nor is it desirable to seek its perfection. The real spiritual goal, at least of classical yoga practice, is to divest oneself of the delusional notion that one is, finally, in any ultimate sense, human at all. Here yoga practice gradually unmasks the illusion that the human mind and the human body have anything to do with authentic identity. And so, from the Christian point of view, one might argue for a deficiency in any view of perfectability in which the human dimension is transcended and left behind altogether. According to Christian theology, whether Protestant, Catholic or Orthodox, the human person in her entirety as this unique historical human being and no other is perfected and completed after death. ${ }^{37}$ And so spiritual attainment in the yoga sense of an inner awakening, as valuable as that might be regarded even from the Christian perspective, is not the same thing as affirming the value and completion of the human person in their totality, in the face of death. The transformation of the human, then, whereby human identity is retained and elevated in the final state of perfection, after one's time on earth has ended, does not seem to me to be regarded even remotely as the cherished final goal of classical or any other type of yoga teaching. But it is the hope of Christians.

Third, in Christianity there is a stronger sense of being held morally accountable to God as Creator and Lord than in postural yoga systems. When morality receives little attention in yoga practice, ${ }^{38}$ chances are there is also no sense of moral accountability before God or a recognition of God's lordship. The "God-within" of contemporary postural yoga does not tend to hold yoga practitioners morally accountable for their actions. ${ }^{39}$ This is not to deny the value of the yamas for the development of one's mind independently of God's commandments and grace, and one might therefore justifiably see oneself as accountable at least to oneself and to one's spiritual growth in the performance of the yamas.

According to Christian teaching God commands people to act with mercy and to practice justice. Jesus brings the poor and the oppressed into the heart of his understanding of what it means to be spiritual, to be in a right relation with God. Here we see how moral accountability before God is measured by the degree people come to the aid of the poor and oppressed. One should therefore not be entirely wrapped up in their private spiritual development. Such an emphasis on justice and responsibility to one's neighbor can make yoga practitioners, including Christian practitioners of yoga, preoccupied with their own private spiritual progress, squirm uncomfortably under the will of God. For God, according to Christian teaching, desires total human liberation, societal as well as individual.

\section{Some Concluding Conciliatory Observations}

In the previous section I highlighted some of the more striking differences between Christian and Hindu/yogic anthropology as well as their two very different understandings of the final goal. But if we now turn our attention for a bit away from these conflicting anthropologies to a more mundane examination of the experience of life in the body we start to notice something that should appear quite obvious. After all the disagreements previously noted we discover a fundamental agreement about life in the body in 
both the Hindu and Christian contexts. We recognize what should be an obvious point of convergence: both Hindus and Christians regard bodily existence in this world as a problem to be overcome. The fact that Christians believe in bodily resurrection after death should not obscure the fact that they regard life in the earthly body as problematic. This is a perception shared by people the world over, whether or not they believe in resurrection, indeed whether or not they believe in God, whether or not they belong to any religion or engage in any spiritual practice. It is not only true for Hindu practitioners of yoga and for Hindu bhaktas, but also for Christian devotees of a personal God, that life in this earthly body is experienced as unsatisfactory. It is in the body that we suffer illness and disease. And as our body ages and withers we suffer a gradual diminishment of our physical and mental powers. All of this is as obviously true for Christians as it is for Hindus.

Christians can therefore recognize the validity of the five kleshas or afflictions connected to life in the body that are named in the $\mathrm{YS}^{40}$ and hope one day to overcome them. They might strive to attain a spiritual state that transcends desire, fear, self-centeredness, and illusion. They might recognize with Patañjali that these afflictions arise almost entirely from an excessive identification with the body, meaning that too much attention to the body can make a person unaware of their spiritual depth and their authentic selfhood. This, I think, is more of a problem in the consumerdriven and body-infatuated western world than it is in India.

We might call this realistic critical assessment of life in the body a "healthy dualism." "Dualism" is normally a much maligned word in Christian theology.
Anthropological dualisms teach that something about us as human beings is intrinsically good and something about us is intrinsically evil and beyond rescuing. It is usually the body and soul that are referred to: the soul is good, but the body is evil. Christianity has combated dualistic attitudes of this type from its very beginnings in Gnosticism, Manichaeism, and various brands of Platonism and Neo-Platonism. It even exists in the minds of Christians today whenever they think that the final goal of the spiritual life is merely for their soul to go to heaven, as if God's promises were for the soul alone and not for the whole human person. Such a dualism, one that ultimately rejects the body, marks classical yoga anthropology, too, as we have seen. The spirit is to divest itself of all matter. But in contrast to this extreme dualism there is a moderate dualism that recognizes that even with the Christian hope for the redemption and transformation of the human person in the resurrection all is not well with the body here on earth 'below.' Besides the gradual decline of the body with the passage of time there is also the problem that the desires and appetites of our material nature must be brought under control; when left unchecked they have the capacity to be a distraction and even an impediment to spiritual growth. That is one of the truths of a healthy dualism shared by both Christians and Hindus.

And in further support of what might be called a moderate dualism is the awareness that we make every day here on earth, namely that we are a reality that transcends our own body. We tend to the body and care for it and suffer from it and experience it as an object of our awareness. So, in a certain sense, we are, in fact, not the body, as Hindus would say, or using a Christian frame of reference, we might say that 
we are more than just our body. Our relation to our own body is such a mysterious thing, with both positive and negative ramifications of our attitudes to it, that it is no wonder that so many interpretations have been given to it by the different religions and philosophies throughout history.

And so, despite the impossibility of harmonizing yoga's extreme anthropological dualism with Christianity's anthropological holism (a more moderate dualism) on the conceptual and doctrinal level, it is important to recognize the shared Hindu and Christian experience that life in the body presents a powerful challenge that must be recognized and addressed.

But in addition to this general human convergence of experience one more thing needs to be made known to the Christian critic of yoga. It is the validity and significance of the yoga experience of interiority, spirit, and transcendence. I believe it would be shortsighted for the Christian to reject the validity and the power of such an experience. Yoga practitioners can made the experience while meditating - even if sometimes gaining an all too brief tantalizing glimpse - of being the changeless witness consciousness, of being pure awareness, of having entered into a timeless state beyond change. Here it is no longer possible to see oneself exclusively as a limited human experiencer of earthly realities or exclusively as a devotee of a personal God. To do so would be to overlook the reality and depth of this particular experience of transcendence and liberation. I believe Christians are challenged today to recognize these two very different experiences of transcendence - the one devotional and relational, centered on love, and the other yogic and non-relational - even when their resulting anthropologies are conceptually and doctrinally very far apart. Both experiences, moreover, as different as they are, the yogic and the Christian, do share at least one important feature. In both instances there is a passing beyond all self-centeredness and impurity. It is the spiritual awareness that "we can only truly be ourselves when we go beyond the ego-self, beyond what we normally believe ourselves to be." ${ }^{" 11}$ The lower self with all its worldly desires, fears, and self-deceptions must finally be annihilated, if freedom is to be attained. These two very different experiences, the one of pure consciousness and the other of love, reveal themselves as true. Bringing them together conceptually presents a problem, of course, but as experiences these two need not be seen as incompatible, whereby the truth revealed in one would necessarily cancel out the truth of the other.

To conclude I would like to address one more issue very briefly, one that is very different from all that has been said so far. This is the frequently articulated objection to yoga put forth by many Christians, namely that by practicing yoga and yogic meditation a person is opening themself to the influence of the demonic. Rather than simply dismissing this objection out of hand as being irrelevant and uninformed about the nature and goal of yoga practice, it is perhaps worth pointing out that in the spiritual traditions of Christianity the practice of prayer is also said to attract the attention of the demons, who would disrupt one's relation with God. To assert that demonic powers are real should not therefore automatically require the Christian to reject yoga as a dangerous and illegitimate spirituality. What is rather of greater importance is for both practitioners of yoga and practitioners of prayer 
to be aware of the reality of the demonic and be on their guard. The danger is perhaps greater for those whose spiritual practice is yoga alone, for the YS says nothing at all about the

\section{Notes}

${ }^{1}$ For some of what follows see my God's Other Children: Personal Encounters with Faith, Love, and Holiness in Sacred India (NY: HarperOne, 2013), 125152.

${ }^{2}$ Recent critical scholarship places Patanjali's YS somewhere in the time span of 350-500 C.E. Though there is no one single ancient authoritative text on yoga practice or metaphysics, the YS does stand out today as the text most frequently cited by Western yoga teachers as the foundation of much contemporary yoga practice. Whether they are correct in grounding contemporary postural yoga in the YS is much debated. As is well known among scholars of yoga and South Asian history, yoga traditions predate the YS by perhaps millennia. Further, these ancient yoga traditions, whose ultimate chronological origins cannot be traced with any reliability, were not necessarily connected to the Indus Valley Civilization. On the historical development of many different yoga systems, both Hindu, Buddhist, and Jain, prior to the modern period, see the summary by Andrea Jain in Selling Yoga: From Counterculture to Pop Culture (New York: Oxford, 2015), 1-19.

${ }^{3}$ Among the many books by B. K. S. Iyengar see especially Light on Yoga (London: Unwin Paperbacks, 1984, orig. 1966) and Light on Life (no location given: Rodale, 2005). A wide-ranging collection of tributes to Iyengar can be found in Iyengar: The Yoga Master, edited by Kofi Busia (Boston and London: Shambhala, 2007). On the life of Iyengar and his understanding of the divine see the insightful essay by Frederick M. Smith and Joan White, "Becoming an Icon: B. K. S. Iyengar as a Yoga Teacher and a Yoga Guru," in Gurus of Modern Yoga, ed. Mark Singleton and Ellen Goldberg (NY: Oxford University Press, 2014), 122-146, especially 134-135. possibility of being afflicted by demonic powers, whereas the reality of the demonic is asserted throughout the New Testament, both in the Gospels and the Epistles.

${ }^{4}$ See especially Yoga: India's Philosophy of Meditation. Edited by Gerald James Larson and Ram Shankara Bhattacharya; Volume XII of the Encyclopedia of Indian Philosophies (Delhi: Motilal Banarsidas, 2008); Edwin Bryant, The Yoga Sūtras of Patañjali (New York: North Point Press, 2009). Klaus K. Klostermaier, A Survey of Hinduism (Albany: SUNY, 1994), pp. 401-407, presents an excellent summary of the Yoga-Sütra. Also useful for yoga studies is Georg Feuerstein, Encyclopedic Dictionary of Yoga (New York: Paragon House, 1990) for analysis of key terms used in texts from within classical and post-classical yoga traditions, both Hindu and non-Hindu, as well as related terms from the Upanishads.

${ }^{5}$ See, in particular, Thomas Ryan, CSP, Prayer of Heart and Body: Meditation and Yoga as Christian Spiritual Practice (New York: Paulist Press, 1995) and John Sheveland, "The Meaningfulness of Yoga to Christian Discipleship," The Way: A Review of Christian Spirituality 47 (July 2008): 49-62. It should be noted that on the website of the United States Conference of Catholic Bishops (www.usccb.org) there are a number of reflections by Catholic authors affirming the value of yoga practice for one's Christian spirituality. This is in contrast to earlier pronouncements coming out of the Vatican that were mostly negative regarding the value of yoga practice and teaching.

${ }^{6}$ As a well known early example see Jean Dechanet, Christian Yoga (London: Search Press, 1970, orig. 1956).

${ }^{7}$ See Andrea Jain, "The Malleability of Yoga: A Response to Christian and Hindu Opponents of the Popularization of Yoga," Journal of Hindu-Christian Studies 25 (2012):3-10. Also, though yoga is usually linked to Hinduism, Buddhism, and Jainism, it has also found a home in Indian Sufi circles. In "The Yogic Exercises of the $17^{\text {th }}$ Century Sufis" Craig Davis 
summarizes the teachings of the Mughal Prince Dara Shukuh, who was the eldest son and heir apparent to the throne of Shah Jahan (builder of the Taj Mahal). Prince Dara was executed by his brother Aurangzeb, but not before leaving behind a treatise describing yogic practices that he or perhaps his Sufi teachers attributed to the Prophet Muhammad himself. Accordingly the Prophet received his first revelation while practicing yoga at Mt. Hira. This essay can be found in Theory and Practice of Yoga: Essays in Honour of Gerald James Larson. Edited by Knut A. Jacobsen (Leiden - Boston: Brill, 2005), 303-316.

${ }^{8}$ See Light on Yoga, 19.

9 These are nonviolence, truthfulness, nonstealing, sexual control, and non-acquisitiveness.

${ }^{10}$ I will return to this point below.

${ }^{11}$ These are purity (of mind, body, and food), contentment, self-mortification or austerity, the study of ourselves and of sacred scripture, and surrender to the Lord.

${ }^{12}$ For what follows see Malkovsky, God's Other Children, 145-147.

${ }^{13}$ Larson, Yoga: India's Philosophy, 49.

${ }^{14}$ See Bryant, Yoga Sūtras.

${ }^{15}$ See "Toward a Fusion of Theological Horizons: Constructivist Reflections and Responses to the Question of Theism in the Yoga Sütra," Journal of Hindu-Christian Studies 25 (2012):25-33.

${ }^{16}$ See Bryant, Yoga Sūtras, 88-89.

${ }^{17}$ Bryant, Yoga Sūtras, 281.

${ }^{18}$ Bryant, Yoga Sūtras, 275.

${ }^{19}$ Larson, Yoga: India's Philosophy, 50.

${ }^{20}$ Bryant, 279, also asserts that YS II.45 ("From submission to God comes the perfection of samadhi.") teaches the grace of the Lord. But the text itself, in fact, says nothing about grace; it speaks rather of the yogi's practice. Grace, if it exists at all, is at best implied.

${ }^{21}$ See Lloyd W. Pflueger, p. 29 of "Person, Purity, and Power in the Yogasūtra," in Theory and Practice of Yoga: Essays in Honour of Gerald James Larson, edited by Kurt A. Jacobsen (Leiden: Brill, 2005), who refers to the Ishvara of the YS as "a rather impersonal and strikingly powerless deity," an understanding that would be transformed in the later commentaries "by the rising current of bhakti."

${ }^{22}$ See Light on Yoga, 39.

${ }^{23}$ Light on Yoga, 9.

${ }^{24}$ Light on Yoga, 19.

${ }^{25}$ Light on Life, 65-66. In the same book (104) he compares the motivation behind pratyahara (withdrawal of the senses) with the yearning expressed in Christian prayer.

${ }^{26}$ Light on Life, 17. Samadhi, he writes, "comes as the fruit of meditation. It arrives by the Grace of God and cannot be forced." (200)

${ }^{27}$ Light on Life, 250.

${ }^{28}$ Light on Life, 201.

${ }^{29}$ Light on Life, 59.

${ }^{30}$ Light on Life, 58, 252.

${ }^{31}$ Light on Life, 86.

${ }^{32}$ Quoted by John Schumacher in Iyengar: The Yoga Master, 72. The context of this quote is not given. I am unable to locate it in any of Mr. Iyengar's writings.

${ }^{33}$ See Smith and White, "Becoming an Icon," 124. The authors add that Iyengar has probably never been seen in public without the Srivaishnava mark on his forehead. (134)

34 "Becoming an Icon," 134.

35 "Becoming an Icon," 134-135.

36 "Person" is a term used of God here in an analogical sense with human personhood, with the understanding that God's mode of personhood is distinguished from human personhood by its absence of finitude and impurity.

${ }^{37}$ But see also the theological problems associated with the Christian teaching of a single earthly life in my "Belief in Reincarnation and Some Unresolved Questions in Catholic Eschatology," Religions 2017, vol. 8, issue 9176: http://www.mdpi.com/2077-1444/8/9/176, 11pp.

${ }^{38}$ See I. K. Taimni, The Science of Yoga (Wheaton, IL: Theosophical Publishing House, 1961), 206-209. Here he speaks of the "relentless ethical code" of the yamas and niyamas, without which it is impossible to reach final liberation. He notes how these are often treated as optional in contemporary yoga practice. 
${ }^{39}$ Of course, such an understanding of divine judgment and human guilt can be experienced as oppressive and lead to various neuroses. See, for example, Tilmann Moser, Gottesvergiftung (Frankfurt: Suhrkamp Verlag, 1976), a now classic best-selling psychoanalytical critique of Christian belief. The title literally means "God poisoning."
${ }^{40}$ The five afflictions named by Patanjali are ignorance, egoism, desire, aversion, and dread of death.

${ }^{41}$ Feuerstein, Encyclopedic Dictionary of Yoga, xx, who writes this in regard to yoga. But I see it as applying to Christian mystical experience, as well. 